\title{
EFFECT OF TEMPERATURE ON INTRINSIC INTESTINAL MOTILITY IN A HIBERNATOR
}

\author{
Eugene H. Studier, T. A. Behrend and Ann L. Freed \\ Department of Biology, University of Michigan-Flint, Flint, \\ Michigan 48503, U.S.A.
}

(Received 29 May 1975)

\begin{abstract}
In titro lowering and raising of the temperature of the initial segment of the small intestine of a homeotherm, the laboratory mouse; Mus musculus, and a hibernator, the big brown bat; Eptesicus fuscus indicate:

1. A direct relationship exists between frequency of contractions and gut temperature which is essentially linear in mice, with contractions ceasing at about $16^{\circ} \mathrm{C}$, and is curvilinear in gut segments from hibernating Eptesicus, with contractions ceasing at about $7^{\circ} \mathrm{C}$.

2. Amplitude of contractions in both species are generally independent of temperature flux; however, in bat gut contraction amplitude drops to very low levels at low temperatures.

3. Relationships to temperature are similar during both cooling and warming of the intestine.

4. Based on motility, the intestine of a hibernator continues to function at a much lower temperature than the gut of a homeotherm.
\end{abstract}

AT THE turn of the century, Bayliss \& Starling (1899) suggested that many factors, including temperature, might relate to mammalian intestinal motility. Although much research has since been completed, the bulk of published accounts (see Code, 1968) appear to deal with the effects of pharmacological agents and innervation as they relate to motility in normal and diseased gastrointestinal tracts. Characterization of gut motility and examination of factors which may affect motor function of the gut are frequently performed by physiology students. Scattered references make passing mention of a direct relationship of temperature and gut motor activity (Puestow, 1932; Ambache, 1947; Milton \& Smith, 1956). We have been unable to locate published accounts of investigations directed specifically toward the description of the relationship of temperature to intrinsic intestinal motility. Although the existence of a relationship of temperature to intestinal motility is physiologically meaningless in homeotherms, gut activity at reduced temperature may be acutely important in animals which hibernate, or in facultative homeotherms. The present study describes the relationship of temperature to frequency and amplitude of intrinsic, myogenic intestinal contractions in a homeotherm, the laboratory mouse (Mus musculus) and a hibernator, the big brown bat (Eptesicus fuscus).

\section{MATERIALS AND METHODS}

Nine adult mice (weight approximately $25 \mathrm{~g}$ ) of both sexes from a colony maintained in the Biology Department were studied. Food was witheld from the mice for $0.5-2 \mathrm{hr}$ prior to experimentation. Ten adult male $E$. fuscus (weight approximately $20 \mathrm{~g}$ ) were collected from a hibernaculum in northeastern Illinois and returned to the laboratory immediately after capture. All bats were maintained in hibernation in a cold room $\left(5-7^{\circ} \mathrm{C}\right)$ for variable periods of time (maximum of $3 \mathrm{wks}$ ) before testing. Some individuals were aroused and utilized in other experimentation prior to this study. Those individuals were fed as many mealworms as they were willing to eat (at least 30 ) during such active periods. Results from such pre-used bats did not differ from results obtained from other bats. Bats were generally given a small drink of water a few min before use.

Individuals of both species were killed by cervical dislocation or a sharp blow to the head. The initial $3 \mathrm{~cm}$ of the intestine were dissected free of mesentery and attached in a muscle warmer filled with warmed Tyrode's solution with the anal end down. The oral end of the segment was attached to a Myograph $A$ which fed signals into a Physiograph (Narco Bio-systems, Inc., Houston, Texas). A slow stream of pure oxygen was continuously bubbled through the bathing solution which was maintained at an initial temperature between 35 and $40^{\circ} \mathrm{C}$ by placing the muscle warmer in a water bath. A minimum amount of tension sufficient to obtain clear recordings was placed on the intestinal segment while recorder amplitude was adjusted to a high constant level. After a few minutes for adjustment and stabilization at the initial temperature, contraction frequency (cycles/min) and amplitude ( $\mathrm{mm}$ of pen sweep/cycle) were recorded. The temperature of the outside water bath was then rapidly lowered by the addition of ice. Recordings of frequency and amplitude were taken at $2^{\circ} \mathrm{C}$ intervals as the Tyrode's solution cooled. This was continued until intestinal motor activity stopped. Throughout the temperature decline, $\mathrm{pH}$ rose from 7.35 at $37^{\circ} \mathrm{C}$ to 7.55 at $5^{\circ} \mathrm{C}$. In most cases, the external water bath temperature was rapidly raised and, again, frequency and amplitudes were recorded at $2^{\circ} \mathrm{C}$ intervals as the Tyrode's solution warmed. No more than $1 \mathrm{hr}$ was required to chill the intestine until it ceased contractions or to warm the preparation to its original starting temperature.

\section{RESULTS}

The relationship of contraction frequency to temperature is illustrated in Fig. 1 for both mice and bats. There appears to be no biologically significant difference between the relationship of contraction frequency to temperature to that during temperature decline or rise for either species. A statistically significant relationship exists between contraction frequency and temperature for both species (mice: $F=2263 \cdot 7$, 


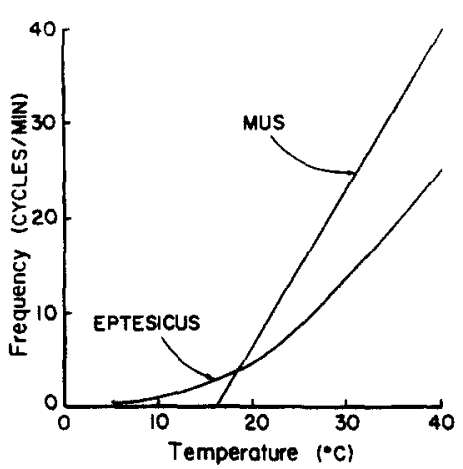

Fig. 1. Relationship of contraction frequency (cycles/min) to temperature $\left({ }^{\circ} \mathrm{C}\right)$ in the initial part of the small intestine in laboratory mice, Mus musculus, and big brown bats, Eptesicus fuscus.

$1 \& 139 d f, P<0.0001$; and, bats: $F=3074 \cdot 1,2 \&$ $248 d f, P<0-0001)$. The relationship for mice is very slightly curved; however, linear analysis provides an excellent descriptive model such that:

$$
\text { Frequency }(\text { cycle } / \mathrm{min})=1.66 \mathrm{Temp} .\left({ }^{\circ} \mathrm{C}\right)-26.5
$$$$
( \pm 0.035)
$$

where the numbers in parenthesis are standard errors. The correlation coefficient $\left(r^{2}\right)$ is 0.94 . In bats, the relationship of contraction frequency to temperature is curvilinear such that:

$$
\begin{aligned}
& \text { Frequency (cycles/min) }= \\
& 0.0189\left[\text { Temp. }\left({ }^{\circ} \mathrm{C}\right)\right]^{2}-0.145 \text { Temp. }\left({ }^{\circ} \mathrm{C}\right)+0.938 \\
& ( \pm 0.0010) \\
& ( \pm 0.046)
\end{aligned}
$$

where the numbers in parenthesis are standard error of the mean and $r^{2}$ is 0.96 .

The average temperature at which contractions stopped in mice was $15.7^{\circ} \mathrm{C}$ and in E. fuscus, it was $7.0^{\circ} \mathrm{C}$. Contraction frequency at normal active temperatures $\left(\mathrm{ca} .37^{\circ} \mathrm{C}\right)$ for big brown bats range from 20-22 contractions/min and for mice range from 35-37 contractions/min.

There was no relationship of temperature to contraction amplitude in mice. Similarly, no consistent affect of temperature flux on contraction amplitude existed in big brown bats except when temperature approached the minimum temperature at which contractions would still occur (i.e., within $2^{\circ} \mathrm{C}$ of minimum), then amplitude dropped markedly.

\section{DISCUSSION}

The contractions measured and reported herein are apparently type I waves as originally described by Foulk et al. (1954). Type I waves are equivalent to rhythmic segmenting contractions of the small intestine and represent either a mixing or a propulsive motor action, or both (Hightower, 1968). The rate of these rhythmic segmentations in the initial part of the small intestine have been measured for several species. In laboratory rats, cats and dogs, Cannon $(1902,1903)$ found contraction frequencies of 44-48, 28-30, and 18-22 contraction cycles/min, respectively. Code et al. (1952) reported 11 contraction cycles per minute for humans. Based on these few data, rate of rhythmic segmenting contractions appears to be inversely related to body weight. Such a relation would not be surprising since weight specific metabolism is inversely related to body weight and rate of gut motility may be indicative of rate of digestion or assimilation. Our data on contraction frequency in lab mice (about 35 contractions $/ \min$ at $37^{\circ} \mathrm{C}$ ) fit this apparent relationship. The extremely slow intrinsic rhythm for $E$. fiscus at active body temperature (about 20 contractions $/ \mathrm{min}$ at $37^{\circ} \mathrm{C}$ ) is doubly surprising since it is small (about $20 \mathrm{~g}$ ) in comparison to the previously mentioned species and might be expected to have a more rapid intrinsic contraction frequency, and also, because bats are known to have extraordinarily rapid digestive passage time (Cranbrook, 1965; Klite, 1965; Luckens et al., 1971; Buchler, 1975).

Rate of rhythmic contractions in any segment of the small intestine is quite constant. It appears to be independent of fasting. eating, sleeping. certain denervation, dietary composition, etc. (Castleton, 1934; Douglas \& Mann, 1939). Segmenting rhythm does decrease in rate as distance from the stomach increases (Legros \& Onimus, 1869; Alvarez, 1914, 1915; Castleton, 1934). Decreasing temperature results in decreased contraction frequency in rabbits (Alvarez, 1914), cats (Bortoff, 1961), dogs (Daniel et al., 1960; Hasselbrack \& Thomas, 1961) and man (Christensen et al., 1966). Certainly contraction frequency and temperature are directly proportional; however, the present study appears to be the first attempt at an accurate quantitative description of this relationship. The essentially linear proportionality found for mice necessitates a continual drop in $Q_{10}$ at increased temperatures. The $Q_{10}$ values drop from 3.48 for $20-30^{\circ} \mathrm{C}$ to 1.7 for $30-40^{\circ} \mathrm{C}$. Since this relationship for $E$. fuscus is curvilinear opening upward, $Q_{10}$ could remain constant or increase: however, it must at least decrease more slowly. The $Q_{10}$-values drop from 4.28 for $5-15^{\circ} \mathrm{C}$ to 2.43 for $20-30^{\circ} \mathrm{C}$ to 1.87 for $30-40^{\circ} \mathrm{C}$. At high temperature, relative gut contraction frequency is less profoundly affected in laboratory mice than in big brown bats. The situation reverses at low temperatures with a higher $Q_{10}$ for mice. Slight fluctuations of a few degrees Celcius result in marked changes in segmenting frequency in both species.

Whereas contractions cease in mouse gut at a temperature of about $15^{\circ} \mathrm{C}$, the gut of the big brown bats taken from hibernation continue to exhibit myogenic segmenting contractions as temperature declines to a level of about $7^{\circ} \mathrm{C}$. Such contractions in hibernators indicate functional digestion throughout much of entry into or arousal from hibernation. Many hibernators periodically arouse from hibemation (Folk, 1940). Some bat species are capable of what appears to be normal flight at reduced body temperatures (Studier \& O'Farrell, 1972). Since some of these species feed during winter flights (O'Farrell \& Bradley, 1970 ), it is energetically advantageous for the digestive apparatus to be operable at the same reduced body temperatures at which flight occurs. Additionally, some summer flying bats which "night roost" are capable of flight and feeding at reduced body temperatures and, again, digestion at lower body temperatures would be energetically advantageous. Under any circumstance if the relationship for big brown bats 
is characteristic of hibernators, the gut will function at reduced temperatures in comparison to homeotherms and these species need not warm to a normal (mid-30 $\mathrm{s}^{\circ} \mathrm{C}$ ) body temperature for functional digestion. In this case, for instance, the gut of E. fuscus appears to function at temperatures greater than about $9^{\circ} \mathrm{C}$. Since some bats hibernate at hibernaculum temperatures of $2-5^{\circ} \mathrm{C}$ (McManus \& Esher, 1971) even a slight arousal may allow for effective digestion.

The amplitude of segmenting contractions are very similar when they occur in rhythmic patterns but vary when contractions occur in irregular patterns (Hightower, 1968). In both species presently under consideration, amplitude of individual contractions varied considerably but in apparently random fashion as there was no relationship of contraction amplitude to temperature. In big brown bats, as the temperature approaches within a few degrees of the minimum level, contraction amplitude abruptly falls to a very low, apparently nonfunctional strength. Therefore, with this single exception, contractions occurring at any temperature are functional segmenting, myogenic contractions.

Acknowledgements - We thank Drs. Richard W. Dapson and Michael J. O'Farrell for their critical evaluations of this manuscript.

\section{REFERENCES}

Alvarez W. C. (1914) Functional variations in contractions of different parts of the small intestine. Am. J. Physiol. 35. 177-193.

Alvarez W. C. (1915) Further studies on intestinal rhythm -II. Am. J. Physiol. 37, 267-281.

AMBACHE N. (1947) The electrical activity of isolated mammalian intestine. J. Physiol., Lond. 106, 139-153.

Bayliss W. M. \& Starling E. H. (1899) The movements and innervation of the small intestine. J. Physiol., Lond. 24, 99-143.

BORTOFF A. (1961) Electrical activity of intestine recorded with pressure electrode. Am. J. Physiol. 201, 209-212.

BUCHLER E. R. (1975) Food transit time in Myotis lucifugus (Chiroptera: Vespertilionidae). J. Mammal. 56. 252-255.

CANivon W. B. (1902) The movements of the intestines studied by means of Röntgen rays. Am. J. Physiol. 6, 251-277.

Cannon W. B. (1903) Further observations on the movements of the stomach and intestine. Am. J. Physiol. 8, 21-22.

Castleton K. B. (1934) An experimental study of the movements of the small intestine. Am. J. Physiol. 107, 641-664.
Christensen J., Clifton J. A. \& SChedl H. P. (1966) Variations in the frequency of the human duodenal basic electrical rhythm in health and disease. Gastroenterolog! 51, 200-206.

CODE C. F. (1968) Alimentary canal-Motility. Handbook of Physiology, Am. Physiol. Soc., Vol. IV. Sect. 6. Washington, $D$. C.

Code C. F., Hightower N. C., JR. \& Morlock C. D. (1952) Motility of the alimentary canal in man. Review of recent studies. Am. J. Med. 13, 328-351.

Cranbrook, Earl of (1965) Grooming by vespertilionid bats. Proc. Zool. Soc., Lond. 145, 143-144.

Daniel E. E., Wachter B. T., Honol'R A. J. \& Bogoch A. (1960) The relationship between electrical and mechanical activity of the small intestine of the dog and man. Can. J. Biochem. Physiol. 38, 777-801.

Douglas D. M. \& ManN F. C. (1939) An experimental study of the rhythmic contractions in the small intestine of the dog. Am. J. Digest. Diseases 6, 318-32?

FoLK G. E., JR. (1940) Shift of population among hibernating bats. J. Mammal. 21, 306-315.

FoulK W. T., CODE C. F., Morlock C. G. \& Bargen J. A. (1954) A study of the motility patterns and basic rhythm in the duodenum and upper part of the jejunum of human beings. Gastroenterology 26, 601-611.

Hasselbrack R. \& Thomas J. E. (1961) Control of intestinal rhythmic contractions by a duodenal pacemaker. Am. J. Physiol. 201, 955-960.

Hightower N. C., JR. (1968) Motor action of the small bowel. Alimentary canal-Motility. Handbook of Physiology, Am. Physiol. Soc., Vol. IV, Chap. 98, Sect. 6. Washington, D.C.

KLITE P. D. (1965) Intestinal bacterial flora and transit time of three neotropical bat species. J. Bucteriol. 90, 375-379.

LEGROS \& ONIMUS (1869) Recherches experimentales sur les mouvements de l'intestin. J. Anat. Physiol. Normal. Pathol. Homme Animaux. 6, 27-66.

Luckens M. M., VAN Eps J. \& Davis W. H. (1971) Transit time through the digestive tract of the bat. Eptesicus fuscus. Exp. Med. Surg. 29, 25-28.

MCManus J. J. \& Esher R. J. (1971) Notes on the biology of the little brown bat, Myotis lucifugus, hibernating in New Jersey. Bull. New Jersey Acad. Sci. 16, 1-2.

Milton G. W. \& SMITH A. W. M. (1956) The pacemaking area of the duodenum. J. Physiol., Lond. 132, 100-114.

O'Farrell M. J. \& Bradley W. G. (1970) Activity patterns of bats over a desert spring. J. Mammal. 51, 18-26.

Puestow C. B. (1932) The activity of isolated intestinal segments. Arch. Surg. 24, 565-573.

Studier E. H. \& O'FARRelL M. J. (1972) Biology of Myotis thysanodes and $M$. lucifugus (Chiroptera: Vespertilionidae)-I. Thermoregulation. Comp. Biochem. Physiol. 41A, 567-595.

Key Word Index-Intestinal motility; hibernation; arousal; bat; Eptesicus; mouse; temperature-gut motility. 